\title{
Electrospun Composite Gel Polymer Electrolytes with High Thermal Conductivity toward Wide Temperature Lithium Metal Batteries
}

Huihui Gan ${ }^{1, \#}$, Jiale Yuan ${ }^{2, \#, ~ Y o n g ~ Z h a n g ~}{ }^{1}$, Shaoqiao Li ${ }^{1}$, Liping Yu ${ }^{1}$, Jirong Wang ${ }^{1}$, Ji $\mathrm{Hu}^{3, *}, \mathrm{Nuo} \mathrm{Yang}^{2 *}$, and Zhigang Xue $\mathrm{e}^{1, *}$

${ }^{1}$ Key Laboratory of Material Chemistry for Energy Conversion and Storage, Ministry of Education, Hubei Key Laboratory of Material Chemistry and Service Failure, School of Chemistry and Chemical Engineering, Huazhong University of Science and Technology, Wuhan 430074, China.

${ }^{2}$ State Key Laboratory of Coal Combustion, and School of Energy and Power Engineering, Huazhong University of Science and Technology, Wuhan 430074, PR China.

${ }^{3}$ School of Materials Science and Engineering, Luoyang Institute of Science and Technology, Luoyang 471023, China.

Number of pages: 10, Number of figures: 13, Number of tables: 2

E-mail addresses: zgxue@mail.hust.edu.cn (Z. Xue); nuo@hust.edu.cn (N. Yang); jhu@lit.edu.cn (J. Hu).

\#These authors contributed equally to this work. 


\section{Table of Contents}

Figure S1. Diameter distributions of es-CPMs fibers $\ldots \ldots \ldots \ldots \ldots \ldots \ldots \ldots \ldots \ldots . \mathrm{S} 3$

Figure S2. BET and BJH pore size distribution of es-CPMs fibers................S3

Figure S3. Pore area and pore size distribution of es-CPMs fibers .................S4

Table S1. Information of PVDF-HFP/AgNWs@ $\mathrm{SiO}_{2}$ es-CPMs .....................S4

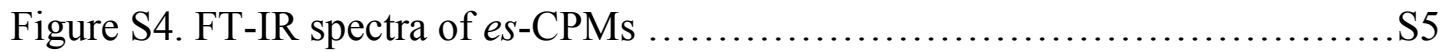

Figure S5. Charge-discharge performance of the cell .......................... 5

Figure S6. Discharge curves of the cell ..................................... S6

Figure S7. Charge-discharge performance of the cell ........................ S6

Figure S8. The dispersity of AgNWs and AgNWs@SiO ${ }_{2}$ in PVDF-HFP matrix......S6

Figure S9. Chemical characterizations of the cycled separator ................. S7

Figure S10. Stress-strain curves of Celgard separator.......................... S7

Figure S11. Charge-discharge performance of the cell..........................S7

Table S2. Comparison of discharge capacity of previous and present work...........S8

Figure S12. Charge-discharge performance of the cell.........................S8

Figure S13. SEM images of lithium metal anode..............................S9 

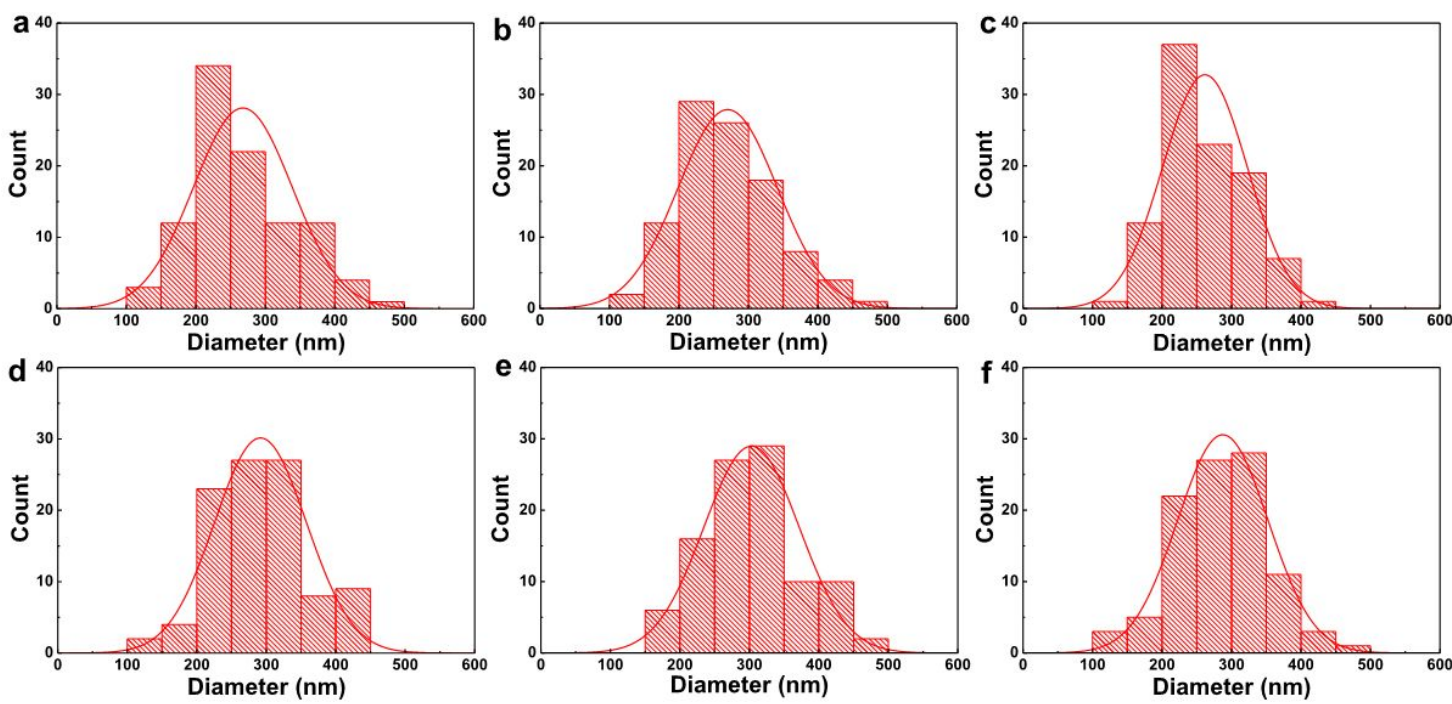

Figure S1. Diameter distributions of PVDF-HFP/AgNWs@SiO ${ }_{2} e s-\mathrm{CPMs}$ fibers with (a) 0 wt $\%$; (b) $1 \mathrm{wt} \%$; (c) $3 \mathrm{wt} \%$; (d) $5 \mathrm{wt} \%$; (e) $7 \mathrm{wt} \%$ and (f) $10 \mathrm{wt} \%$ of $\mathrm{AgNWs} @ \mathrm{SiO}_{2}$.
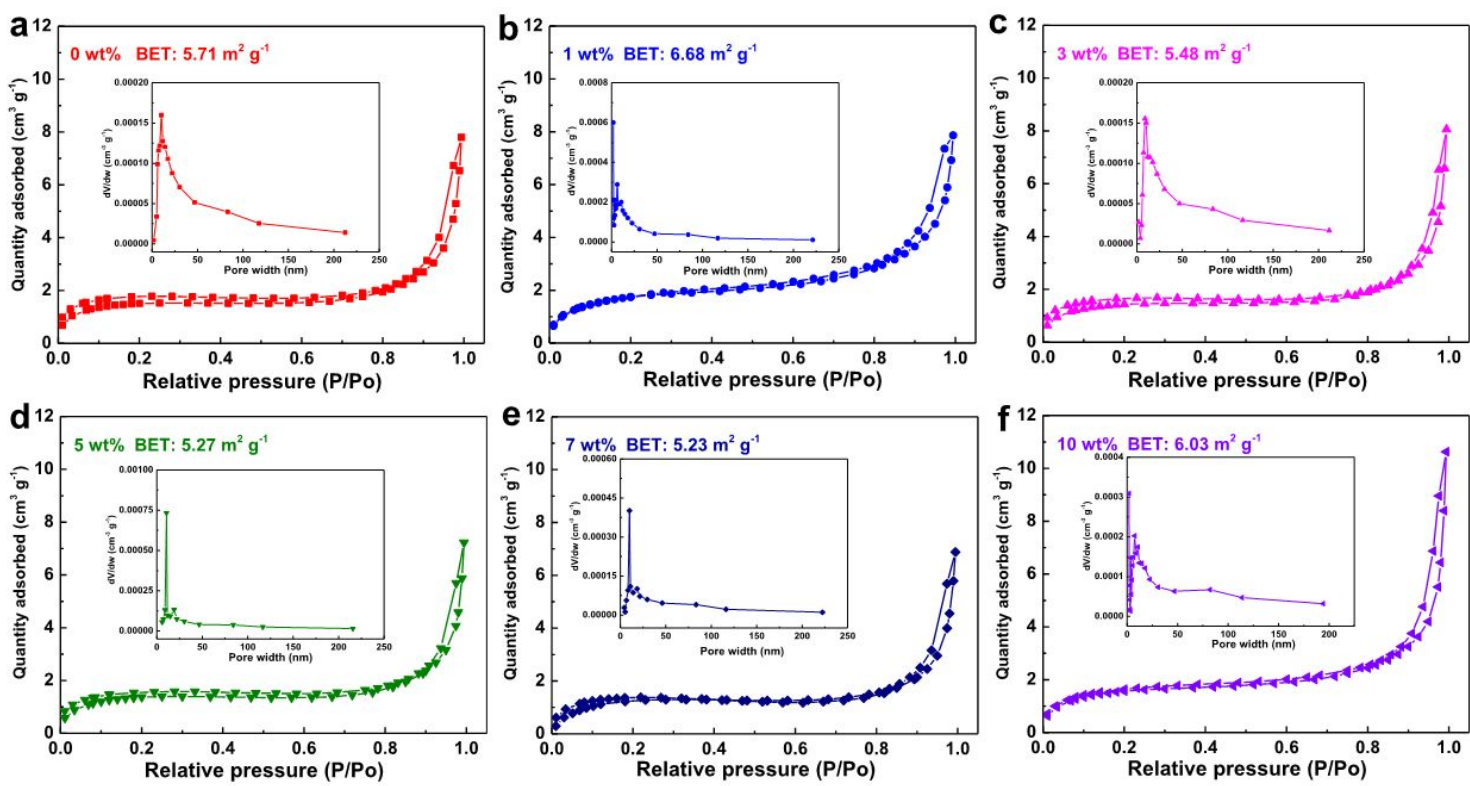

Figure S2. $\mathrm{N}_{2}$ adsorption/desorption isotherms and BJH pore size distribution of (shown in inset)

PVDF-HFP/AgNWs@SiO $\mathrm{Si}_{2} e s-\mathrm{CPMs}$ fibers with (a) $0 \mathrm{wt} \%$; (b) $1 \mathrm{wt} \%$; (c) $3 \mathrm{wt} \%$; (d) $5 \mathrm{wt} \%$; (e) 7 wt $\%$ and (f) 10 wt $\%$ of AgNWs@ $\mathrm{SiO}_{2}$. 

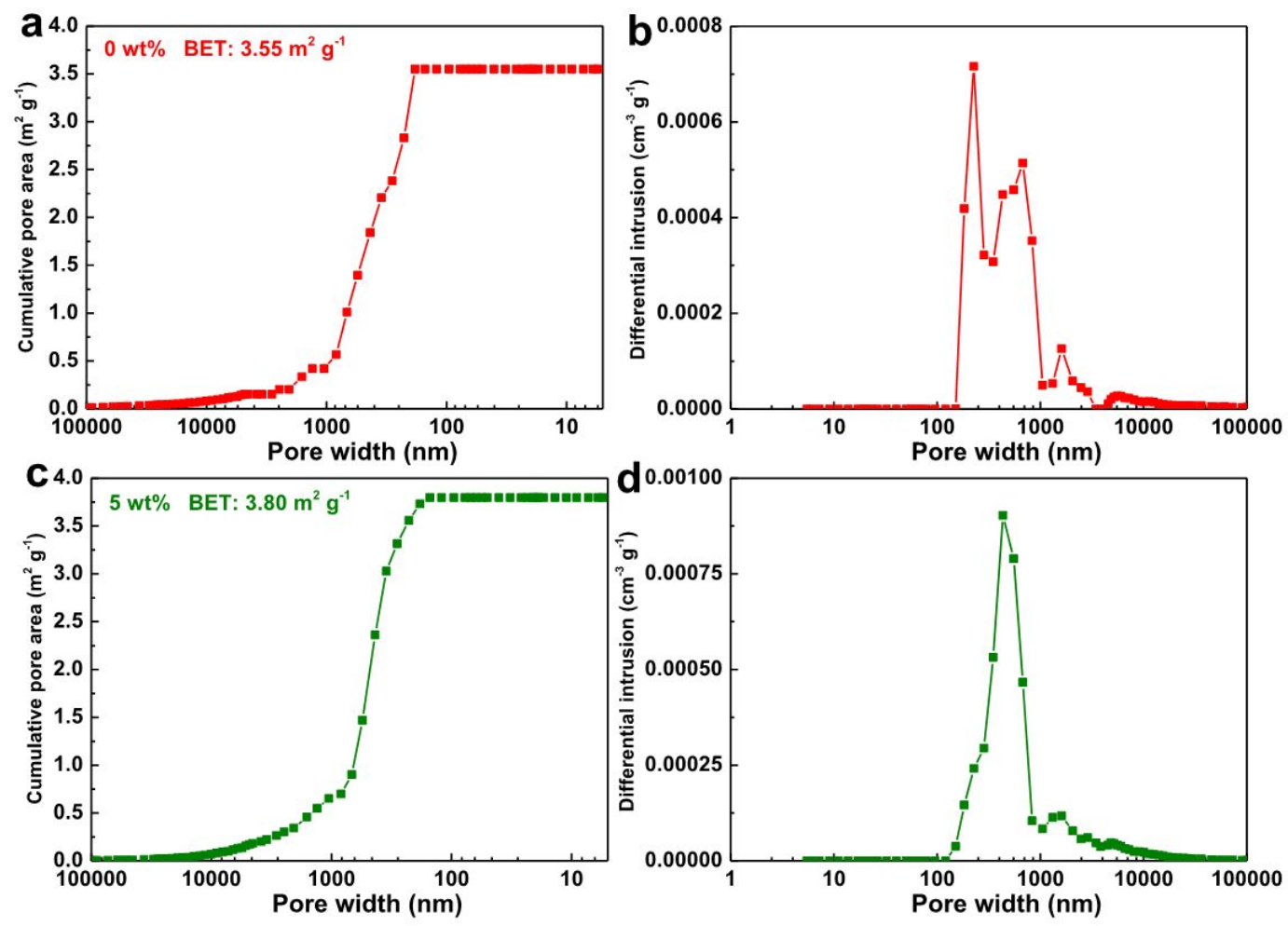

Figure S3. Pore area and pore size distribution of PVDF-HFP/AgNWs@ $\mathrm{SiO}_{2}$ es-CPMs fibers with (a) and (b) 0 wt \%; (c) and (d) 5 wt $\%$ of AgNWs@ $\mathrm{SiO}_{2}$.

Table S1. Information of Stress, Strain, Heat of Fusion $(\Delta H)$, Crystallinity $\left(X_{\mathrm{c}}\right)$ and Ionic conductivity for PVDF-HFP/AgNWs@SiO ${ }_{2}$ es-CPMs.

\begin{tabular}{|c|c|c|c|c|c|c|}
\hline $\begin{array}{c}\mathrm{AgNWs} @ \mathrm{SiO}_{2} \\
(\mathrm{wt} \%)\end{array}$ & $\begin{array}{l}\text { Stress } \\
(\mathrm{MPa})\end{array}$ & $\begin{array}{l}\text { Strain } \\
(\%)\end{array}$ & $\begin{array}{c}T_{\mathrm{m}} \\
\left({ }^{\circ} \mathrm{C}\right)\end{array}$ & $\begin{array}{c}\Delta H \\
\left(\mathrm{~J} \mathrm{~g}^{-1}\right)\end{array}$ & $\begin{array}{l}X_{\mathrm{c}} \\
(\%)\end{array}$ & $\begin{array}{l}\text { Ionic conductivity } \\
\left(\mathrm{S} \mathrm{cm}^{-1} \text {, at } 60^{\circ} \mathrm{C}\right)\end{array}$ \\
\hline 0 & 5.6 & 70 & 155.8 & 42.6 & 40.7 & $2.30 \times 10^{-3}$ \\
\hline 1 & 6.1 & 90 & 156.1 & 37.6 & 35.9 & $2.74 \times 10^{-3}$ \\
\hline 3 & 7.7 & 126 & 156.3 & 41.8 & 39.9 & $2.62 \times 10^{-3}$ \\
\hline 5 & 7.0 & 117 & 156.4 & 39.4 & 37.6 & $2.54 \times 10^{-3}$ \\
\hline 7 & 6.0 & 115 & 156.3 & 40.0 & 38.2 & $2.49 \times 10^{-3}$ \\
\hline 10 & 5.4 & 128 & 155.4 & 39.0 & 37.2 & $2.77 \times 10^{-3}$ \\
\hline
\end{tabular}

The crystallization degree $\left(X_{\mathrm{c}}\right)$ of $e s$-CPMs was calculated by the equation: 


$$
X_{\mathrm{c}}=\frac{\Delta H}{\Delta H_{\mathrm{m}}}
$$

where $\Delta H_{\mathrm{m}}$ is standard fusion enthalpy of $100 \%$ crystalline PVDF $\left(104.7 \mathrm{~J} \mathrm{~g}^{-1}\right)^{1}$ and $\Delta H$ is the fusion enthalpy of es-CPMs.

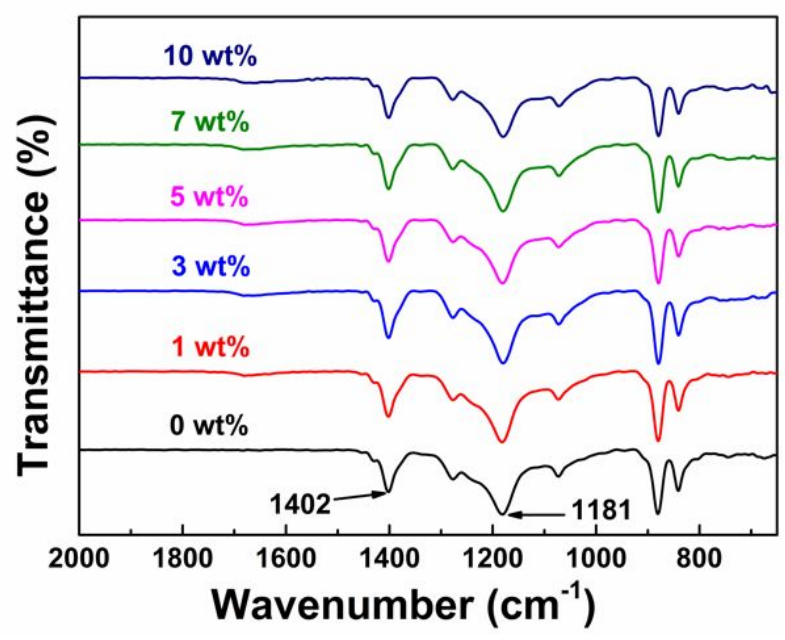

Figure S4. FT-IR spectra of PVDF-HFP/AgNWs@ $@ \mathrm{SiO}_{2}$ es-CPMs. 

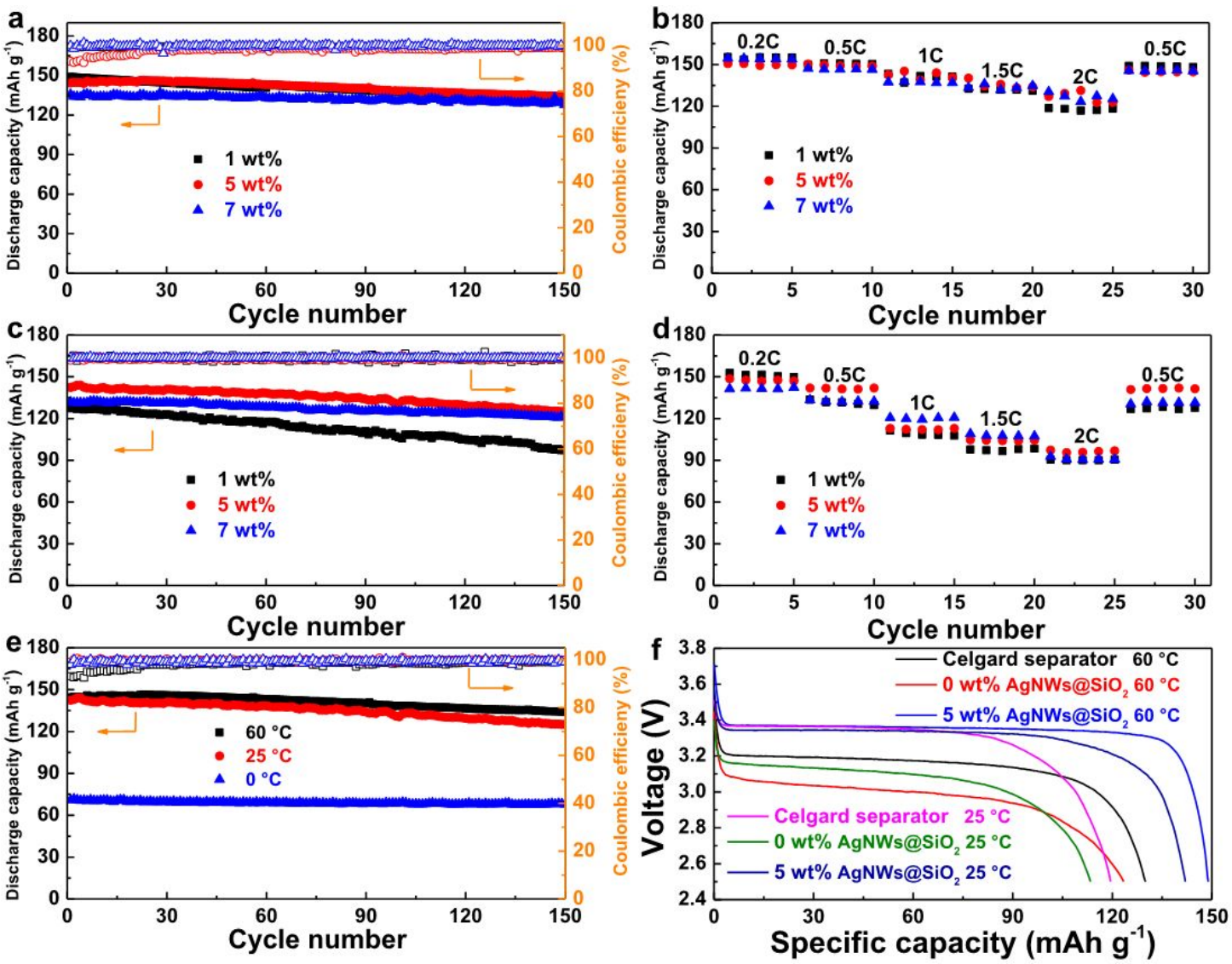

Figure S5. (a) Cycling performance of Li/es-CGPEs/LFP cells operated at $0.5 \mathrm{C}$ at $60{ }^{\circ} \mathrm{C}$. (b) Rate performance of $\mathrm{Li} /$ es-CGPEs/LFP cells at different rates of $0.2,0.5,1,1.5$ and $2 \mathrm{C}$ at $60{ }^{\circ} \mathrm{C}$. (c) Cycling performance of Li/es-CGPEs/LFP cells operated at $0.5 \mathrm{C}$ at $25{ }^{\circ} \mathrm{C}$. (d) Rate performance of $\mathrm{Li} / e s$-CGPEs/LFP cells at different rates of $0.2,0.5,1,1.5$ and $2 \mathrm{C}$ at $25{ }^{\circ} \mathrm{C}$. (e) Cycling performance of $\mathrm{Li} /$ es-CGPEs/LFP cells based on $5 \mathrm{wt} \% \mathrm{AgNWs} @ \mathrm{SiO}_{2}$ at $0.5 \mathrm{C}$ at 0,25 , and 60 ${ }^{\circ} \mathrm{C}$. (f) Discharge curves of the Li/es-CGPEs/LFP cells at $0.5 \mathrm{C}$.
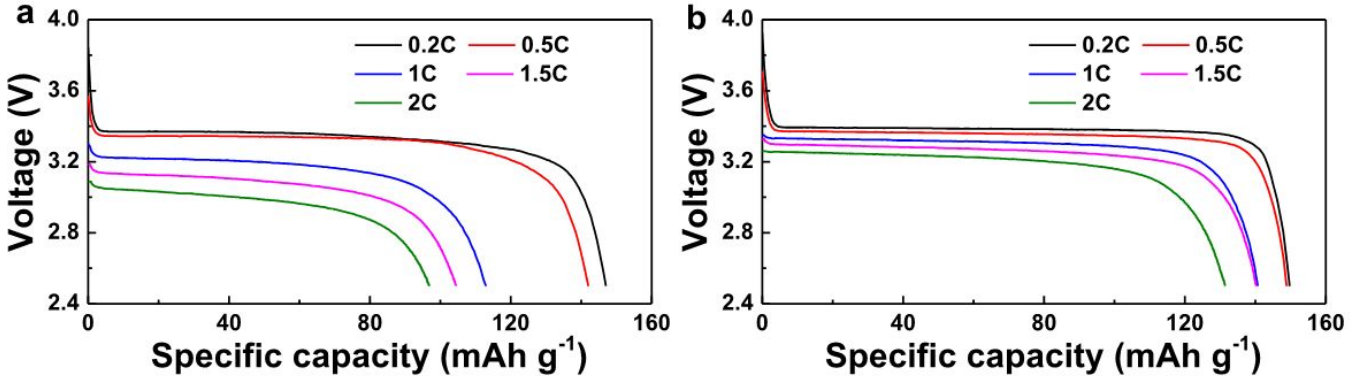

Figure S6. Discharge curves of Li/es-CGPEs/LFP cells based on 5 wt $\%$ AgNWs@ $@ \mathrm{SiO}_{2}$ at different rates of $0.2,0.5,1,1.5$ and $2 \mathrm{C}$. (a) at $25^{\circ} \mathrm{C}$. (b) at $60^{\circ} \mathrm{C}$. 

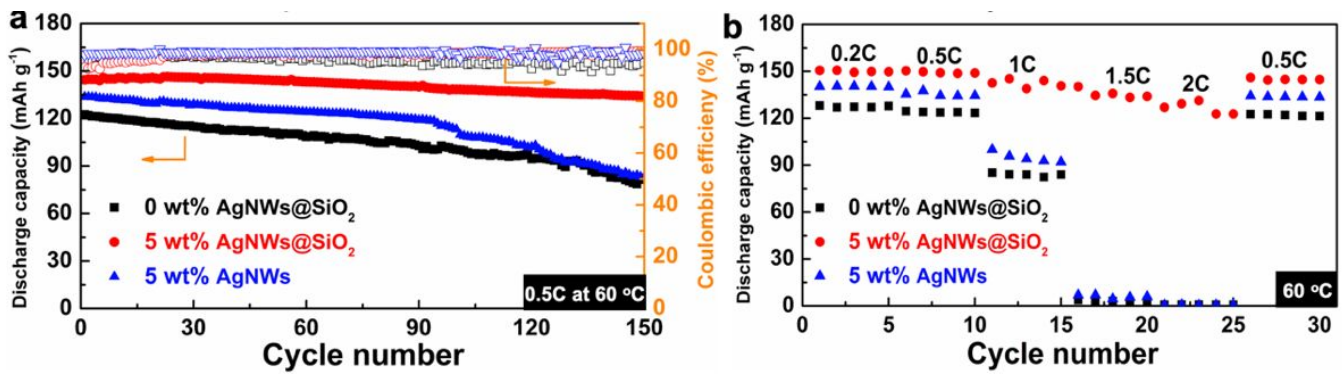

Figure S7. (a) Cycling performance of Li/es-CGPEs/LFP cells assembled with PEs based on AgNWs or AgNWs@ $\mathrm{SiO}_{2}$ operated at $0.5 \mathrm{C}$ at $60{ }^{\circ} \mathrm{C}$. (b) Rate performance of Li/es-CGPEs/LFP cells assembled with PEs based on AgNWs or AgNWs@SiO $\mathrm{Si}_{2}$ at different rates of 0.2, 0.5, 1, 1.5 and $2 \mathrm{C}$ at $60^{\circ} \mathrm{C}$.
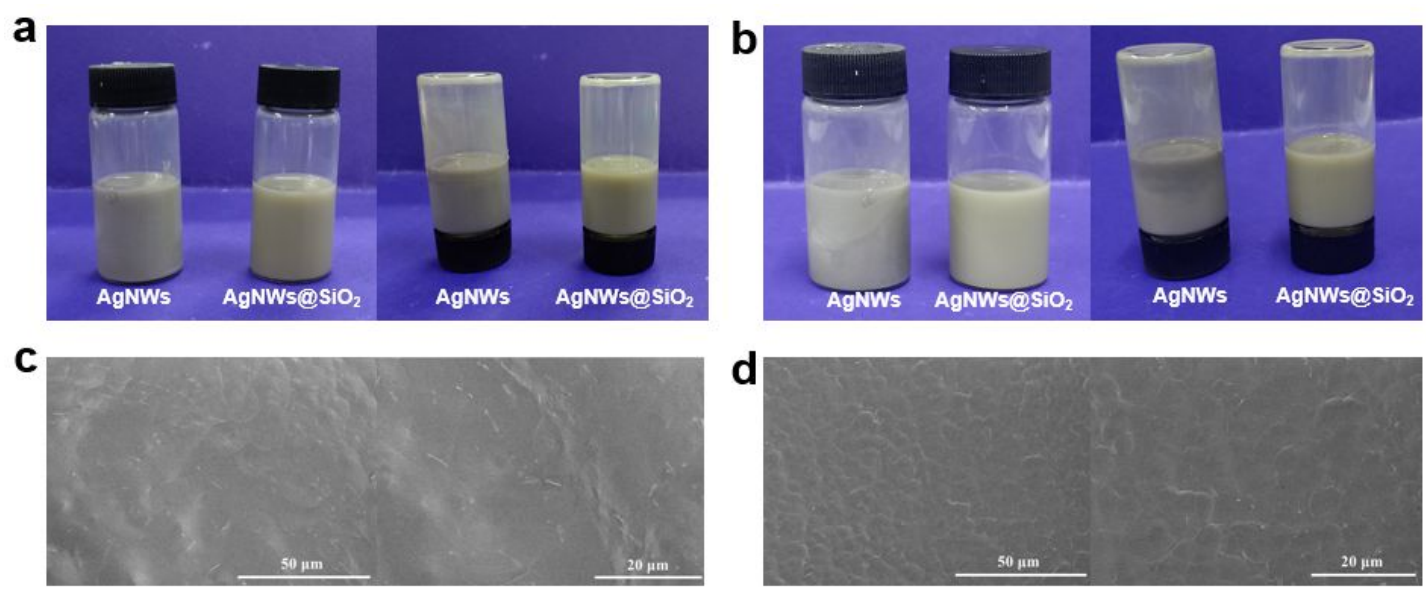

Figure S8. The dispersity of AgNWs and AgNWs@SiO $\mathrm{SiO}_{2}$ in PVDF-HFP matrix. PVDF-HFP dispersed in DMF and acetone with 5 wt $\%$ AgNWs or 5 wt $\%$ AgNWs@ $\mathrm{SiO}_{2}$ to rest for (a) $0 \mathrm{~h}$ and (b) 4 h. SEM images of PVDF-HFP with 5 wt $\%$ of (c) AgNWs and (d) AgNWs@SiO $\mathrm{SiO}_{2}$. 

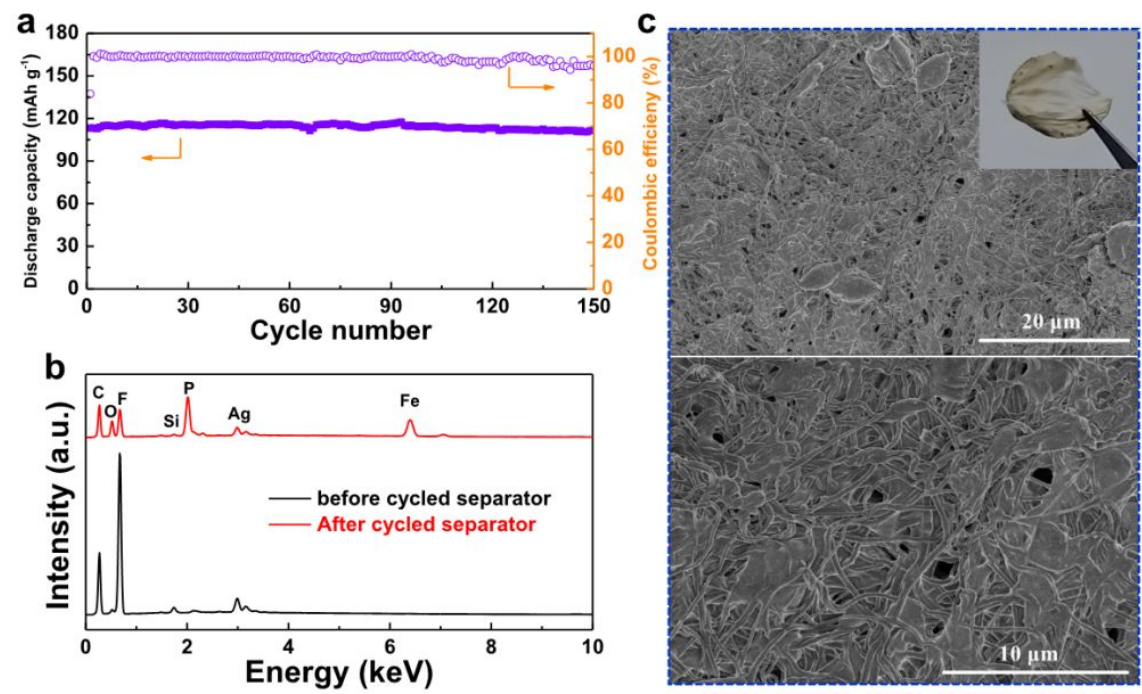

Figure S9. (a) Cycling performance of Li/es-CGPEs/LFP cells with 5 wt $\%$ of AgNWs@ $\mathrm{SiO}_{2}$ operated at $1 \mathrm{C}$ at $25{ }^{\circ} \mathrm{C}$. (b) EDAX spectrum of before and after cycled separator with $5 \mathrm{wt} \%$ of AgNWs@ $\mathrm{SiO}_{2}$ operated for 150 cycles at $1 \mathrm{C}$ at $25^{\circ} \mathrm{C}$. (c) SEM images of after cycled separator.

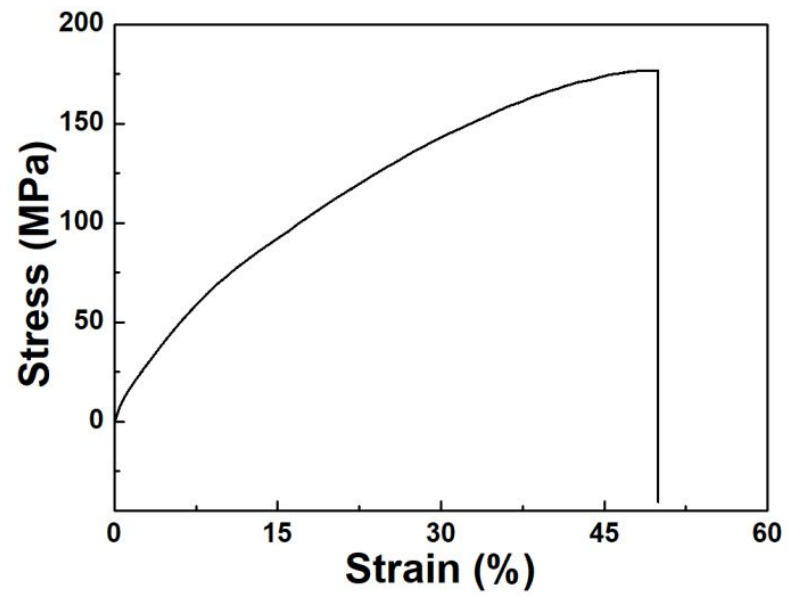

Figure S10. Stress-strain curves of Celgard separator.
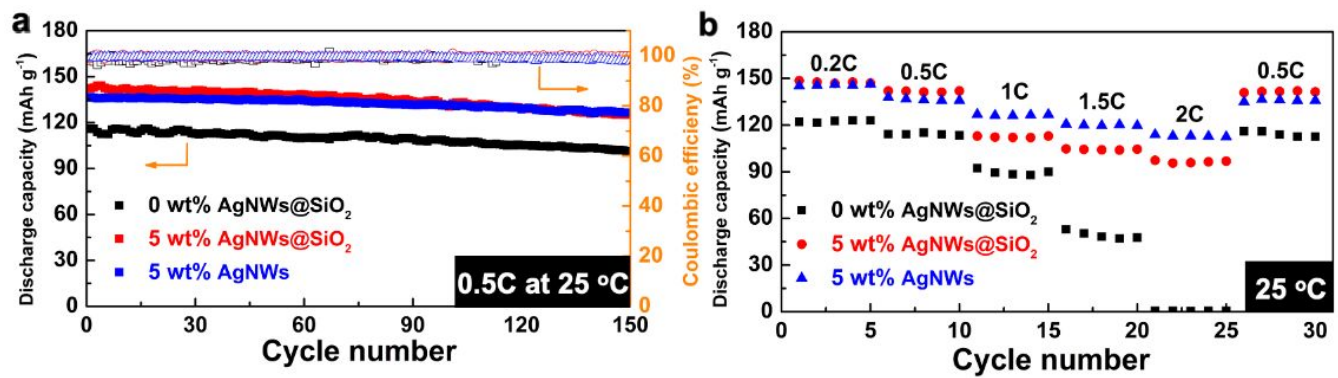

Figure S11. (a) Cycling performance of Li/es-CGPEs/LFP cells assembled with PEs based on 
AgNWs or AgNWs@SiO 2 operated at $0.5 \mathrm{C}$ at $25{ }^{\circ} \mathrm{C}$. (b) Rate performance of Li/es-CGPEs/LFP cells assembled with PEs based on AgNWs or AgNWs@SiO $\mathrm{Si}_{2}$ at different rates of 0.2, 0.5, 1, 1.5 and $2 \mathrm{C}$ at $25^{\circ} \mathrm{C}$.

Table S2. Comparison of discharge capacity of $\mathrm{Li} / / \mathrm{LFP}$ cell at different rates and cycling performance at $25^{\circ} \mathrm{C}$ reported in the previous and present work.

\begin{tabular}{|c|c|c|c|c|c|}
\hline Sample & $\begin{array}{l}\text { Method of } \\
\text { fabrication }\end{array}$ & $\begin{array}{l}\text { Liquid } \\
\text { electrolyte }\end{array}$ & $\begin{array}{l}\text { Discharge capacity } \\
\text { (C-rate, } \mathrm{mA} \mathrm{h} \mathrm{g}^{-1} \text { ) }\end{array}$ & 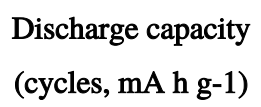 & Ref. \\
\hline PVDF-HFP/ & Electro & $1 \mathrm{M} \mathrm{LiPF}_{6}$ in & $146.3(0.5 \mathrm{C})$ & 150 cycles & This \\
\hline $5 \mathrm{wt} \% \mathrm{AgNWs}$ & spinning & $\mathrm{EC} / \mathrm{EMC} / \mathrm{DEC}$ & $112.5(2 \mathrm{C})$ & $126.4(0.5 \mathrm{C})$ & work \\
\hline PVDF-HFP/ & Electro & $1 \mathrm{M} \mathrm{LiPF}_{6}$ in & $142.0(0.5 \mathrm{C})$ & 150 cycles & This \\
\hline 5 wt\%AgNWs@ $\mathrm{SiO}_{2}$ & Spinning & $\mathrm{EC} / \mathrm{EMC} / \mathrm{DEC}$ & $96.8(2 \mathrm{C})$ & $125.1(0.5 \mathrm{C})$ & work \\
\hline \multirow[t]{2}{*}{ PMIA@PVDF-HFP } & Electro & $1 \mathrm{M} \mathrm{LiPF}_{6}$ in & $137(0.5 \mathrm{C})$ & 100 cycles & (2) \\
\hline & Spinning & $\mathrm{EC} / \mathrm{EMC} / \mathrm{DEC}$ & $119(2 C)$ & $122.7(0.2 \mathrm{C})$ & \\
\hline $\mathrm{PP} / \mathrm{PE}$ multilayer & template & $1 \mathrm{M} \mathrm{LiPF}_{6}$ in & $\sim 130(0.5 \mathrm{C})$ & 50 cycles & (3) \\
\hline separator & method & $\mathrm{EC} / \mathrm{EMC} / \mathrm{DMC}$ & $\sim 110(2 \mathrm{C})$ & $131(0.2 \mathrm{C})$ & \\
\hline $\mathrm{PVdF} / \mathrm{SiO}_{2}$ composite & Electro & $1 \mathrm{M} \mathrm{LiPF}_{6}$ in & $\sim 140(0.5 \mathrm{C})$ & 50 cycles & (4) \\
\hline nonwoven membranes & Spinning & $\mathrm{EC} / \mathrm{DEC}$ & $\sim 115(1 \mathrm{C})$ & $159(0.2 \mathrm{C})$ & \\
\hline AAO@PVDF-HFP & AAO & $1 \mathrm{M} \mathrm{LiPF}_{6}$ in & $\sim 150(0.2 \mathrm{C})$ & 360 cycles & (5) \\
\hline composite separator & template & $\mathrm{EC} / \mathrm{DEC}$ & $\sim 75(2 \mathrm{C})$ & $140(0.2 \mathrm{C})$ & \\
\hline PAN/HCNFs@ & Electro & $1 \mathrm{M} \mathrm{LiPF}_{6}$ & $140.9(0.5 \mathrm{C})$ & 100 cycles & (6) \\
\hline PVDF/UiO-66 & Spinning & solution & $\sim 123(2 \mathrm{C})$ & $\sim 150(0.2 \mathrm{C})$ & \\
\hline $15 \mathrm{wt} \%[$ Emim $][\mathrm{TFSI}] /$ & Electro & $1 \mathrm{M} \mathrm{LiPF}_{6}$ in & $\sim 130(0.5 \mathrm{C})$ & 50 cycles & (7) \\
\hline PVDF membranes & Spinning & $\mathrm{EC} / \mathrm{DMC}$ & $\sim 90(2 \mathrm{C})$ & $70(2 \mathrm{C})$ & \\
\hline
\end{tabular}
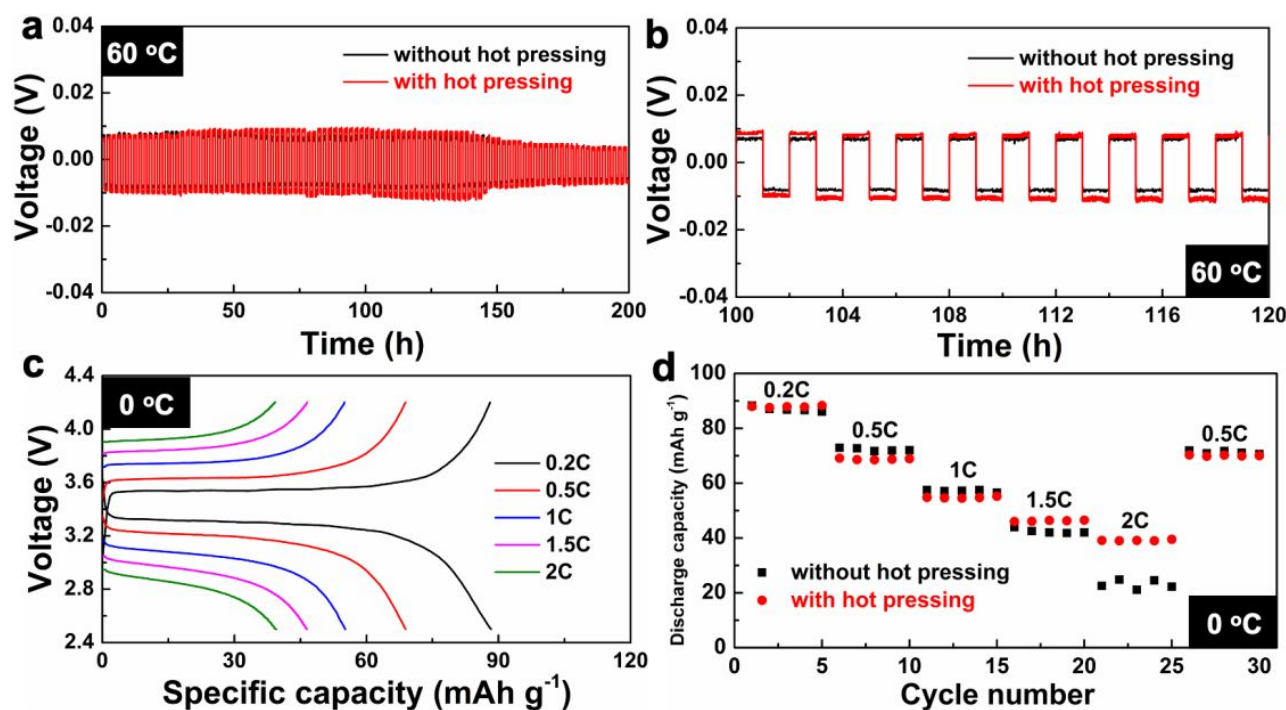

Figure S12. (a) Voltage-time curves of $\mathrm{Li} / e s-\mathrm{CGPEs} / \mathrm{Li}$ symmetric cell based on $5 \mathrm{wt} \%$ AgNWs@ $\mathrm{SiO}_{2}$ at a constant current density of $0.5 \mathrm{~mA} \mathrm{~cm}{ }^{-2}$ at $60{ }^{\circ} \mathrm{C}$. (b) Enlarged voltage-time profiles at 100-120 h. (c) Charge-discharge curves of Li//LFP cell at different rates with hot-pressed es-CGPEs at $0{ }^{\circ} \mathrm{C}$. (d) Rate performance of $\mathrm{Li} / / \mathrm{LFP}$ assembled with or without 


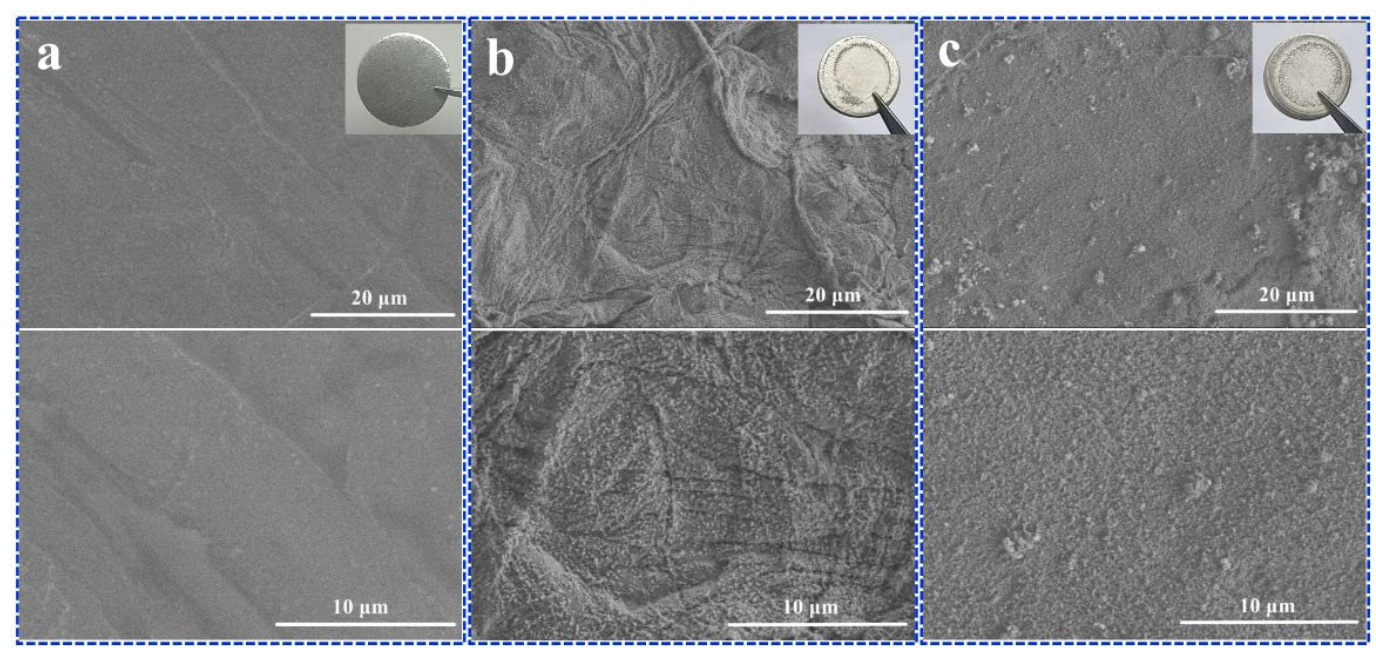

Figure S13. Voltage-time curves of $\mathrm{Li} /$ es-CGPEs/Li symmetric cell based on $5 \mathrm{wt} \%$ AgNWs@ $\mathrm{SiO}_{2}$ at a constant current density of $0.5 \mathrm{~mA} \mathrm{~cm}-2$ at $60{ }^{\circ} \mathrm{C}$ (inset is the corresponding digital pictures). SEM images of pristine lithium metal (a), lithium metal anode with without hot-pressed es-CGPEs (b) and with hot-pressed es-CGPEs (c).

\section{REFERENCES}

(1) Cao, J.-H.; Zhu, B.-K.; Xu, Y.-Y. Structure and Ionic Conductivity of Porous Polymer Electrolytes Based on PVDF-HFP Copolymer Membranes. J. Membr. Sci. $2006,281,446-453$.

(2) Chen, Y.; Qiu, L.; Ma, X.; Chu, Z.; Zhuang, Z.; Dong, L.; Du, P.; Xiong, J. Electrospun PMIA and PVDF-HFP Composite Nanofibrous Membranes with Two Different Structures for Improved Lithium-Ion Battery Separators. Solid State Ion. 2020, 347, 115253.

(3) Li, Y; Pu, H.; Wei, Y. Polypropylene/Polyethylene Multilayer Separators with Enhanced Thermal Stability for Lithium-Ion Battery via Multilayer Coextrusion. Electrochim. Acta 2018, 264, 140-149.

(4) Zhang, F.; Ma, X.; Cao, C.; Li, J.; Zhu, Y. Poly(vinylidene fluoride)/SiO $\mathrm{S}_{2}$ 
Composite Membranes Prepared by Electrospinning and Their Excellent Properties for Nonwoven Separators for Lithium-Ion Batteries. J. Power Sources 2014, 251, 423-431.

(5) Wu, Z; Cai, Z; Fang, B; Liu, M; Wu, H; Liu, A; Y, F. A Polar and Ordered-Channel Composite Separator Enables Antidendrite and Long-Cycle Lithium Metal Batteries. ACS Appl. Mater. Interfaces 2021, 13, 25890-25897.

(6) Fu, Q.; Zhang, W.; Muhammad, I. P.; Chen, X.; Zeng, Y.; Wang, B.; Zhang, S. Coaxially Electrospun PAN/HCNFs@PVDF/UiO-66 Composite Separator with High Strength and Thermal Stability for Lithium-Ion Battery. Microporous Mesoporous Mater. 2021, 311, 110724.

(7) Barbosa, J. C.; Correia, D. M.; Gonçalves, R.; de Zea Bermudez, V.; Silva, M. M.; Lanceros-Mendez, S.; Costa, C. M. Enhanced Ionic Conductivity in Poly(vinylidene fluoride) Electrospun Separator Membranes Blended with Different Ionic Liquids for Lithium Ion Batteries. J. Colloid Interface Sci. 2021, 582, 376-386. 